\title{
The halo effect of foreign brands on the misclassification of local brands
}

\author{
Sulhaini SULHAINI \\ Department of Management, The University of Mataram, Lombok-Indonesia \\ sulhaini@unram.ac.id \\ Baiq Handayani RINUASTUTI \\ Department of Management, The University of Mataram, Lombok-Indonesia \\ hrinuastuti@unram.ac.id \\ Dwi Putra Buana SAKTI \\ Department of Management, The University of Mataram, Lombok-Indonesia \\ dwiputrabs@unram.ac.id
}

\begin{abstract}
Consumers generally lack the ability to identify brands' true origins, with their attribution of the wrong origins to well-known brands showing their underlying attitudes. This study suggests that the misclassification of local brands in Indonesia is driven by the halo effect of foreign brands (i.e., brands from Japan, South Korea and China) and the inferior image of locally made products. These constructs, however, differently affect Indonesian consumers' attitudes towards local brands. This study strongly suggests that, when consumers misperceive local brands as being from more developed countries, they tend to show negative attitudes towards local brands. This study provides useful recommendations for both local and foreign brand owners seeking strategies to enhance competitiveness in the Indonesian market.
\end{abstract}

Keywords: halo effect, brand identity misclassification, inferior image of local products, consumer attitudes.

\section{Introduction}

The country of origin (COO) effect has attracted scholars in the field of international marketing for many years. This concept is associated with the country of manufacture or assembly, as referenced in the phrase "made in ...", and explains that more favourable country images create better perceptions of and preference for products that originate in particular countries. However, as hybrid products have become prevalent in the global market, this concept has proven untenable. As such, the brand origin concept has been developed, holding that consumers assess the image of particular countries not only by considering specific production abilities but also by assessing more the comprehensive competencies related to brand generation (Panda and Kapoor, 2016; Mandler et al., 2017). Together, these concepts suggest that the COO effect can be seen either in consumers' images of either specific products or of brands in specific product categories. A country with a positive reputation in certain product categories may also have reputable brands in the global market, with the positive image of these brands carrying over to all brands that originate in the country in question. This suggests a halo effect, in which an impression created in one area influences impressions elsewhere (Lee et al, 2016).

As the brand origin concept has flourished, a number of authors (Zhuang et al., 2008; Zhou et al., 2010; Balabanis and Diamantopoulos, 2011; Magnusson et al., 2011; Mandler et al., 2017; Sulhaini et al, 2019) have suggested that consumers generally lack the ability to identify brands' true origin and often attribute the wrong origin to wellknown brands; this, they argue, underlines consumers' attitudes towards these brands. This has been particularly common in developing countries such as Indonesia (Sulhaini 
and Sagir, 2015; Sulhaini et al., 2019) and China (Zhuang et al., 2008; Zhou et al., 2010), where local brands are not clearly recognised as such by consumers. Previous authors, however, have not explored how origin misclassification can be attributed to the strength of foreign brands' halo effect and the inferior image of local products. Furthermore, no published research has shown how the halo effect of foreign brands and the poor image of local products affect domestic consumers' attitudes towards local brands. To address this research gap, this study links the concepts of COO and halo effect with the concepts of local brand misclassification and local brand attitudes. Filling this gap will be of value for future study.

Given the objective above, we organise this paper as follows. We first review the literature in order to develop a definition of the variables of interest and facilitate our development of hypotheses. Subsequently, we highlight the methods of the study before discussing its results and important managerial implications.

\section{Literature review and hypothesis development Strength of the halo effect of foreign brands}

Country image has been widely suggested as affecting consumer behaviour, creating a halo effect on both products and brands. COO information acts as a cognitive cue for consumers, leading them to generalise the attributes of products/brands from particular countries. In other words, COO information acts as a cue for consumers who are unfamiliar with specific products/brands, enabling them to infer brand attributes based on the source country (Mandler et al., 2017). When consumers are unable to evaluate a brand's true quality, they turn to their image of its source country to assess the quality of the brands. This may suggest that halo effects occur in situations where brand information is not sufficiently available. However, Han (2016) has shown that highfamiliarity brands such as Toyota and Honda also have strong indications of a halo effect among South Korean consumers. We may thus conclude that even well-known or strong brands are not independent of the image of their home country, and as such the halo effect can emerge regardless of consumer brand knowledge level.

Two types of halo are identified in COO literature; these two types explain consumers' tendency to maintain cognitive consistency in their memories (Mandler et al., 2017). First, the image of a brand's COO acts a halo, with consumers making inferences about brands from a particular country based on their image of or stereotypes about said country. When consumers evaluate brands from a given country, they rely on their memories of brand knowledge or search for information from other sources. However, when such information is unavailable, consumers tend to simplify the process by inferring information about the source country or utilising their impressions of it. In this type of halo, the image of a country serves as a signal that allows consumers to make inferences about a particular brand or product category from it. This type of halo is known as a salient trait halo, as the image of the brand's source country acts as a salient trait (Oh and Ramaprasad, 2003). COO is a secondary source of brand associations (Sulhaini et al., 2019), with consumers generally relying on country image as the dominant association (Vanceet al., 2016). Consumers' perception of a brand is thus underlined by their image of the brand's source country; they refer to this information when evaluating brands even when brands' specific products are produced elsewhere (Koubaa, 2008).

Second, brands from the same country may have a halo effect on each other, showing consumers' tendency to allow their evaluation of a specific brand to influence their opinions of all other brands; this type of halo is known as an inter-trait halo $\mathrm{OH}$ and 
Ramaprasad, 2003). Consumers' knowledge of one particular brand will influence their perceptions of other brands from the same COO. This may be caused by consumers having limited knowledge/information about other brands, or just simply viewing such knowledge as unimportant and thus not actively seeking it. Consumers rely on their prior experiences with a particular brand; this brand, thus, has a halo effect on all brands from the same country. In other words, consumers generalise the quality of other brands from a particular country based on their prior knowledge of a specific brand from said country. This suggests a chain of effect among brands originating from the same country (Lee et al., 2016), since consumers view brands as having similar quality standards or product development processes owing to their shared COO (Borah and Tellis, 2016). Prior knowledge thus affects consumers' views of other brands' attributes (quality, value, performance, technology, etc.) as they are seen as highly interrelated and similar. This type of halo generates evaluations in which brands from the same COO are seen as having slight/no differences. Given that, in inter-trait halos, consumers' initial perceptions of the first brand they use is influenced by country image, it can be argued that this type of halo is not independent of the image of the source country. As such, to measure the strength of the halo effect of foreign brands, this study relies on the general impression of all brands from particular countries; a favourable image of a source country is reflected in all brands from the same country being favourably perceived.

Based on its origin, a brand can be classified as foreign or local. This origin, as well as the popular perceptions of it, influences consumers' perceptions and attitudes, thereby generating brand origin stereotypes. It has been widely argued that, in developing countries, consumers favour foreign brands due to positive stereotypes. Consumers view foreign brands-particularly those from more developed countries-as having higher quality and using more advanced technology owing to their stereotypes of these countries. Simply put, consumers' attitudes towards a brand depends on their image of its source country, since the image is often transferred to the brand (Bruwer et al., 2014). Consumers infer brand attributes/associations based on their evaluation of the COO's economic, political, technological, and industrial development (Sulhaini et al., 2019). This suggests that brands from developed countries enjoy a strong positive halo effect, being viewed more favourably than those from developing countries, which are affected by a negative halo effect. Consumers in developing countries tend to exhibit positive attitudes towards foreign brands and imported products, especially those from more developed countries, as they make inferences according to their images and generalised impressions of those countries (Bhardwaj et al., 2010). Likewise, consumers tend to perceive foreign brands as better than local brands, suggesting that consumers in developing countries view their homelands as inferior in product and brand production. Their perception of domestic products/brands is influenced by what they think of their own countries (Sulhaini, 2016). This is not to say that strong local brands cannot emerge in developing countries; these brands may emerge and offer high-quality goods (Özsomer, 2012), butowing to their strong preference for foreign brands-consumers will hold misperceptions about them (Chang, 2008, Zhuang et al. ,2008; Zhou et al., 2010; Sulhaini et al., 2019). It is therefore reasonable to argue that, as they do not expect strong local brands to exist in the domestic market and misperceive their own countries' capabilities, consumers in developing countries will misclassify strong local brands as foreign ones. They will assume that all favoured brands available in the domestic market come from other (more developed) countries.

Consumers sometimes use their image of a brand's source country in evaluating a brand when they lack information or knowledge of said brand's true quality. The image 
of a brand's COO indirectly influences attitudes towards said brand; as such, the image acts as a halo and indirectly affects attitudes towards the brand (Bloemer et al., 2009). Consumers rely on their knowledge of the source country to simplify their brand evaluation process and make inferences regarding the quality of the brand. If they view the brand's COO favourably, they will have a positive attitude towards the brand. As consumers in developing countries tend to have a positive attitude towards foreign brands and a negative attitude towards local brands, we propose the following hypotheses:

$\mathrm{H1}$ : The stronger the halo effect of foreign brands, the greater the misclassification of local brands by domestic consumers

H2: The stronger the halo effect of foreign brands, the more negative consumers' attitudes towards local brands.

\section{Inferior images of local products}

Consumers often utilise their impression of a brand's source country to evaluate brands, ignoring other specific attributes. They assume that brands from highly industrialised countries are of superior quality, as they believe that said countries' technological capabilities must result in better brand/product quality (Mandler et al., 2017). Simply put, the more developed a country, and the more positive its image, the more favourably consumers perceive the quality of its brands. This again suggests a halo effect in brand evaluation, whereby consumers tend to have a global impression of brands from particular countries based on their perceptions of said countries. Brand image is associated with country image, and thus varies from one country to another.

In product evaluation, brands from developed countries tend to benefit from this halo effect. Developed countries tend to be more favourably perceived by consumers, and - consequently—so are their brands (Mandler et al., 2017; Sulhaini et al., 2019). Conversely, a source country being negatively perceived can ruin the image of its brands. Consumers prefer products/brands from countries that they perceive as having superior capabilities and a reputation for producing high-quality products/brands. This can result in consumers having less confidence and pride in local brands, a trend that has proven particularly problematic among consumers in developing countries (Balabanis and Diamantopoulos, 2011).

A review of the literature shows that consumers in developing countries often view locally made products as inferior (Sulhaini, 2016). This can be seen, for example, in Indonesia, where the country is perceived by consumers-both domestic (Sulhaini and Mulyono, 2015; Sullhaini and Sagir, 2015) and international (Chu et al., 2010)-as producing inferior electronic products. Since a country's image affects consumers' attitudes towards both products and brands from that particular country (Mandler et al., 2017), it is reasonable to assume that, when consumers hold an inferior image of their country, they will have an inferior image of local brands. They may even tend to misclassify strong local brands as foreign, a situation compounded by brands' use of the "foreign look strategy" to conceal their localness (Zhou et al., 2010). Therefore, it is reasonable to propose the following hypotheses:

H3: The more inferior the image of domestic products, the greater the misclassification of local brand identity.

H4: The more inferior the image of domestic products, the more negative the consumer attitude towards local brands.

\section{Local brand identity misclassification}


Brand identity is formed through brand associations that are strategically developed by brand owners to shape consumers' preferences; this identity gives consumers a particular image of the brand (Sääksjärvi and Samiee, 2011). As a brand's COO can be a secondary source of brand associations, it informs the brand's identity. Favourable country associations generate advantages for brands from that country, while unfavourable country associations generate disadvantages (Spence and Essoussi, 2010).

Brand identity creates uniqueness/distinctiveness for a brand. It involves not only the names and symbols (Ghodeswar, 2008), but all brand associations-including COOthat brands use to distinguish themselves from their competitors. Clear and distinctive brand identities, thus, offer a strategic means for brand owners' to distinguish themselves from their competitors in consumers' minds by helping consumers identify and evaluate their brand. Brands may develop differentiated elements in their marketing, creating and conveying an intended identity and image, perhaps one that appears glamourous, foreign (read: western), or modern lifestyle.

Brand identity is distinct from, but related to, brand image. Brand identity, as explained above, represents a brand distinctiveness created through brand owners' marketing activities. Brand image, meanwhile, is created in consumers' minds and reflects how brand identity is perceived by consumers; it is thus the result of the interplay between corporate marketing activities and consumers' minds. Put simply, while both are products of communication, brand identity is on the corporate side, while brand image is on the consumer side (Srivastava, 2011). Local brand identity misclassification, thus, refers to consumers' perceiving local brands as foreign due to their favourable identities. It is also reasonable to say that, when consumers have favourable images of local brands due to the favourable identities attached to them, there is a greater tendency for said consumers to classify/perceive these brands as foreign.

Özsomer (2012) writes that, compared to foreign brands, local brands have a stronger local identity and thus a more powerful market position. They can be strong icons in their domestic markets as they are associated with symbols of the local culture, heritage, and country. However, in developing countries, domestic consumers tend to show a greater preference for foreign brands or behave favourably towards foreign brands even when they do not offer superior quality and value over local brands (Pham and Richards 2015). In their evaluation process, consumers search for information that seems relevant to them. However, this information is sometimes unavailable or not equally sought and evaluated. Consumers tend to hold over-simplified views because they judge brands based on their knowledge of their COO (Sulhaini et al., 2019). Accordingly, local brand owners tend to mask the true origin of their brand, thereby "hiding" the secondary source of brand association. Such local brands, particularly in emerging markets, imitate foreign brand identities to derive such benefits as better brand images and equity-enhancing favourable consumer attitudes by "dressing up foreign". A "foreign" image is cultivated by local brands seeking to take advantage of developed countries' favourable image (Zhou et al., 2010).

Consumers identify the $\mathrm{COO}$ of a brand based on their views of the identity attached with it, including that identity presented through its brand name or advertising (Sulhaini et al., 2019). A brand communicates what its owner wants it to convey. However, brand owners often adapt their brands to the changing nature of consumer preference. As such, recognizing that local brands are perceived unfavourably, companies in developing countries tend to use naming and advertising strategies that result in consumer confusion regarding the brand's true origin. Local companies in developing countries position their brands as foreign by employing foreign names, symbols, logos, 
and languages in their advertising, seeking to leverage consumers' perceptions of the superiority of their brands. They deliberately imitate foreign identities, which leads to consumers misclassifying their brands' actual origins and preferring them over their competitors' (Zhuang et al., 2008). Such misclassification plays a significant role in brand attitude (Zhuang et al., 2008; Zhou et al., 2010; Balabanis and Diamantopoulos, 2011; Magnusson et al., 2011), as consumers' attitudes are influenced by their knowledge of brands' (misperceived) COO. Consumers have more favourable attitudes towards branded products that originate from countries they perceive favourably than branded products from countries they perceive less favourably. Additionally, brands of Western origin are accepted in Asia's emerging markets more widely than Asian brands due to their Western identity (Pham and Richards, 2015). It is therefore reasonable to assume that, when consumers misclassify strong local brands, they still have a negative attitude towards brands that they recognise as local. Therefore, the hypothesis below is proposed. H5: The greater the local brand identity misclassification, the more negative the consumer attitude towards local brands.

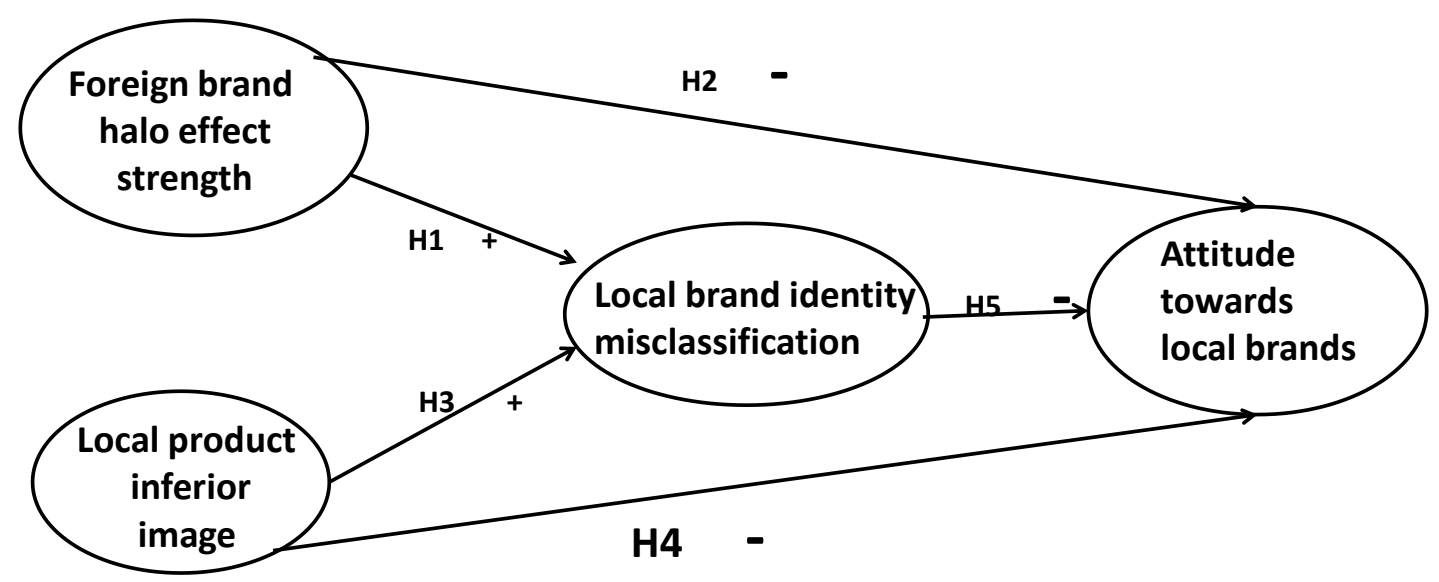

Figure 1. Theoretical Framework

\section{Methods}

\section{Country selection}

Japan, South Korea and China have been the main source of electronic products and brands in the Indonesian market. These countries are known globally as Asia's main industrialised countries and have become symbols of Asian development in terms of technology, industry and economy. These countries enjoy a favourable image as a source of good-quality electronic products (Sulhaini and Mulyono, 2015).

\section{Sample and data collection}

Data were collected through self-administered questionnaires distributed among the students of nine faculties at the University of Mataram, Lombok, Indonesia. Respondents were briefly told what the questionnaire was about and were provided with short, clear instructions on how to answer it. A total of 300 questionnaires were distributed; after 
removing the outliers and incomplete questionnaires, 251 questionnaires were retained for further analysis. This sample consisted of first-year (48.6\%), second-year (31.2\%), and third-year (20.2\%) students, all between 17 and 24 years of age; $44.4 \%$ of respondents were male and $55.6 \%$ were female. In terms of origin, $49.4 \%$ of respondents came from Lombok Island, 33.5\% came from Sumbawa Island, 12.6\% came from the islands of Java and Bali, and the remainder (4.5\%) came from other islands in Indonesia (Sumatra, Celebes, and Papua).

\section{Measurement}

We operationalised the strength of the halo effect of foreign brands as the degree to which consumers evaluate brands from Japan, South Korea and China, based on their image of these countries. Items measured in this construct were "high value", "great", "remarkable performance", "high quality", and "symbol of advanced technology". Meanwhile, local brand identity misclassification is operationally defined as consumers' perception of local brands as foreign due to said brands favourable identities. Items measured in this construct were "positive reputation", "prestige", "glamourous appearance", "foreign name", and "modern look"; for the first item, reverse coding was used, with respondents being given a list of popular local brands and asked to classify the brands as local or foreign according to their knowledge. The inferior image of local products was operationalised as the degree to which consumers have a negative impression of locally made electronic products. This was measured using an adaptation of the eleven product cues proposed by Diamantopoulos, Schlegelmilch, and Palihawadana (2009) - design, product innovativeness, model variety, technological advancement, operating performance, overall quality, durability, prestige, value for money, price attractiveness, and product serviceability. Meanwhile, attitude towards local brands refers to consumers' feelings (like/dislike), preferences, and opinions regarding local brands in the electronic product category. All items on the questionnaire were written in Indonesian.

Respondents were asked to rate every statement on the questionnaire on a scale from 0 to 10 . The questionnaire consisted of five parts that were deliberately structured to avoid framing respondents. The first part collected descriptive information regarding respondents; subsequent sections ascertained respondents' attitudes toward local brands, local brand identity misclassification, halo effect of foreign brands, and inferior image of locally made products.

All items on the instrument were carefully developed in order to maintain content validity. Instrument development involved several steps, beginning with review of the relevant literature and discussions with colleagues in the Department of Management at the University of Mataram, Lombok. Through these steps, we obtained useful insights and richer items. Finally, the items were sent to a senior and reputable lecturer in marketing management at the University of Diponegoro, Central Java, Indonesia. Necessary modifications were made in response.

\section{Measure validation}

For validation, we carried out confirmatory factor analysis on all measures, where each item was allowed to load only on its proposed construct. Seven items had factor loading that was lower than the threshold of 0.50 (Hair et al., 2010) and were thus removed from the instrument; a total of 19 items were retained as they had factor loading greater that the threshold. Cronbach's alpha values and Composite Reliability (CR) were also greater than the common cut-off value of 0.70 (Hair et al., 2010). Furthermore, we calculated the 
Average Variance Extracted (AVE) for each construct. The resulting values were above the common threshold of 0.50 (Hair et al. 2010), demonstrating the reliability and convergent validity of the scales. The measurement results are displayed in the Appendix. Meanwhile, for discriminant validity testing, we compared the square root of the AVE of each construct to its correlation with the other construct (Fornell and Larcker 1981). The results are displayed on Table 1 . In all cases, the AVE was greater than the squared correlation. These results confirmed discriminant validity. Also, the measurement model reached a good fit to the data. Furthermore, the model fit statistic of each country under study showed that the measurement model was a good fit to the data, i.e. Japan: CMIN/DF: 1.732; GFI:0.865; AGFI: 0.838; NFI: 0.818; TLI: 0.904; CFI: 0.913; RMSEA: 0.054; South Korea: CMIN/DF: 1.857; GFI: 0.858; AGFI: 0.830; NFI: 0.821; TLI: 0.897; CFI: 0.907; RMSEA: 0.059; and China: CMIN/DF: 1.701; GFI: 0.866; AGFI: 0.839; NFI: 0.834; TLI: 0.915; CFI: 0.924; RMSEA: 0.053.

Table 1. Discriminant validity

\begin{tabular}{|l|llll|}
\hline & 1 & 2 & 3 & 4 \\
\hline Strength of Foreign brand halo effect (1) & $(0.707)$ & & & \\
Attitude towards local brands (2) & -0.300 & $(0.737)$ & & \\
Inferiority image of local products (3) & 0.245 & -0.359 & $(0.717)$ & \\
Local brand identity misclassification (4) & 0.331 & -0.525 & 0.553 & $(0.756)$ \\
\hline
\end{tabular}

All significant at $p<.05$, the diagonal (in italics) shows the square root of the average variance extracted for each construct

\section{Results}

We utilised a structural equation modelling technique with AMOS 22 to test all hypotheses. The structural model of each country studied achieved an excellent level of fit, i.e. Japan: CMIN/DF: 1.186; GFI: 0.933; AGFI: 0.912; NFI: 0.924; TLI: 0.985; CFI: 0.987; RMSEA: 0.027; South Korea: CMIN/DF: 1.187; GFI: 0.930; AGFI: 0.908; NFI: 0.925; TLI: 0.985; CFI: 0.987; RMSEA: 0.027; and China: CMIN/DF: 1.134; GFI: 0.933; AGFI: 0.913; NFI: 0.928 TLI: 0.989; CFI: 0.991; RMSEA:0 .023. The results of hypothesis testing are displayed below.

Table 2. The results of hypotheses test.

\begin{tabular}{|c|c|c|c|c|c|c|}
\hline \multirow[t]{2}{*}{ Hypothesis } & \multicolumn{2}{|c|}{ Japan } & \multicolumn{2}{|c|}{ S, Korea } & \multicolumn{2}{|c|}{ China } \\
\hline & $\beta$ & $t$ value & $\beta$ & $t$ value & $\beta$ & $t$ value \\
\hline $\begin{array}{l}\text { H1. The stronger the halo } \\
\text { effect on foreign brands is, } \\
\text { the greater local brand } \\
\text { identity misclassification } \\
\text { among domestic consumers }\end{array}$ & 0.240 & $2.958^{* *}$ & 0.291 & $3.067^{* *}$ & 0.190 & $2.374^{*}$ \\
\hline $\begin{array}{l}\text { H2. The stronger the halo } \\
\text { effect on foreign brands is, } \\
\text { the more negative consumer } \\
\text { attitude towards local brands }\end{array}$ & -0.128 & -1.854 & -0.236 & $-3.346^{* * *}$ & -0.090 & -1.583 \\
\hline $\begin{array}{l}\text { H3: The more inferior the } \\
\text { image of domestic products is, }\end{array}$ & 0.661 & $5.571^{* * *}$ & 0.785 & $6.175^{* * *}$ & 0.858 & $6.699^{* * *}$ \\
\hline
\end{tabular}




\begin{tabular}{|c|c|c|c|c|c|c|}
\hline $\begin{array}{l}\text { the greater } \\
\text { misclassification of local } \\
\text { brand identity }\end{array}$ & & & & & & \\
\hline $\begin{array}{l}\text { H4: The more inferior the } \\
\text { image of domestic products is, } \\
\text { the more negative the } \\
\text { consumer attitude towards } \\
\text { local brands }\end{array}$ & -0.094 & -1.073 & -0.067 & -0.783 & -0.109 & -1.232 \\
\hline $\begin{array}{l}\text { H5. The greater the local } \\
\text { brand } \\
\text { misclassification is, the more } \\
\text { negative the consumer } \\
\text { attitude towards local brands }\end{array}$ & -0.356 & $-4.156^{* * *}$ & -0.273 & $-4.270^{* * *}$ & -0.306 & $-4.600^{* * *}$ \\
\hline
\end{tabular}

Note: Significant at : ${ }^{*} p<0.01^{* *} p<0.005$; and ${ }^{* * *} p<0.0001$

The results suggest that, although some paths are not supported by our data for each country studied, Hypotheses 3 and 5 are well supported by our data for all three countries. Interestingly, those countries show variations with regard to Hypotheses 1 and 2. The strength of the halo effect on brands seems to vary among industrialised Asian countries. The standardised beta coefficient of the halo effect strength of brands from China (significant at $p<0.01$ ) is the lowest among all of the countries studied. This construct has an insignificant impact on Indonesian consumers' attitudes towards local brands, and thus Hypothesis 2 is not supported. Nevertheless, the strength of the halo effect of brands from China has a strong, negative, and indirect impact on Indonesian consumers' attitudes through their inability to classify local brands $(0.190 \times-0.090=-$ 0.017 ) significant at $p<0.001$. Hypothesis 2 is strongly supported for South Korea, while the halo effect on brands from Japan is rather weak. It is worth noting, however, that the effect could not be definitely ignored or excluded because the path is significant at $p<0.1$. Furthermore, since only the direction is supported by our data, Hypothesis 4 is partly supported. Nonetheless, it is worthwhile to examine the indirect effects of these countries' images on the image of local products and attitudes towards local brands. The indirect effects are as follows: Japan $(0.661 \mathrm{x}-0.356=-0.235)$; South Korea $(0.785 \mathrm{x}$ $0.273=-0.214)$ and China $(0.858 \times-0.306=-0.262)$, all of which are significant at $p<$ 0.000. It is predicted by $\mathrm{H} 5$ that local brand identity misclassification is significantly and negatively related to domestic consumers' attitudes towards local brands. The data indicates that this hypothesis is strongly supported for the three industrialised Asian countries studied.

\section{Discussion}

Hypothesis 1 expects that the halo effect of brands from the industrialised Asian countries studied has a positive impact on Indonesian brand identity misclassification. The results indicate that the halo effect of brands from these countries has an effect on Indonesian consumers' inability to classify local brands. However, the halo effect of brands from China is weaker than that of brands from other countries. The halo effect of brands from Japan and South Korea generates confusion among Indonesia consumers, as they have the general impression that all brands from those countries have high value, high quality, advanced technology, and remarkable performance. This perception 
cultivates their inability to identify local brands, especially when local brands make a favourable impression regarding reputation and glamour. When consumers find local brands with favourable identities, they will misclassify them as foreign ones. The localness of these brands also seems unclear, as said brands use foreign brand names.

Furthermore, it is expected that the halo effect of brands from those three countries has a great impact on domestic consumers' negative attitudes towards local brands. Nonetheless, the study indicates that the halo of brands from South Korea has the greatest effect on domestic consumers' negative attitude towards local brands; the strength of the halo of brands originating from the country generates negative feelings about local brands. Indonesian consumers seem to have negative feelings about local brands, while they have strong positive perceptions of brands from South Korea and Japan. Meanwhile, the halo effect of brands from China is not strong enough to generate negative attitudes towards local brands. This may mean that Indonesian consumers do not see brands originating in China as higher quality and value than local brands.

Diamantopoulos, Schlegelmilch, and Palihawadana (2009) argued that consumers often associate their image of products and brands with their image of the $\mathrm{COO}$, particularly that country's perceived ability to produce products and brands. A country with a favourable image and high ability to produce particular products will have the capacity to build strong brands, and vice versa. This study indicates that local products are negatively perceived, leading domestic consumers to misclassify strong local brands. Domestic consumers perceive their home country as a developing country, and thereby as lacking the technological capacity to develop high-quality electronic products. This contributes to consumers' belief that there are no strong or reputable brands.

Sulhaini and Mulyono (2015) found that Indonesian consumers perceived locally made electronic products to be of lower quality than products from those industrialised Asian countries. The current study suggests that this negative perception leads consumers to misclassify local brands. When they have an unfavourable image of locally made products, consumers are unable to identify reputable local brands. They seem to perceive reputable local brands as non-existent owing to their unfavourable image of locally made electronic products. When local brands have favourable identities, confusion occurs, as consumers believe that domestically made products are unfavourable and that local brands cannot be reputable or prestigious. It seems that consumers have a strong belief that reputable brands with favourable identities and foreign brand names are not locally developed or owned by local companies. Rather, they simply identify these brands as foreign. The study indicates that the misclassification of local brand identities is stronger affected by the inferior image of the local products than the strength of halo effect of brands from those industrialised Asian countries.

For all countries, the path between the image of local products and attitude towards local brands is not supported by the data, meaning that the inferior image of locally made electronic products does not negatively affect domestic consumers' attitudes towards local brands. When consumers have a negative perception of locally made electronic products' quality, design, innovativeness, technology, durability, service ability, product performance, and value, they will not necessarily demonstrate a negative attitude. They will still like local brands; they just do not know that reputable brands exist in the market. Therefore, the study suggests that, even when domestic consumers have an unfavourable perception of locally made electronic products, this only generates consumer confusion about local brand identity. It does not nurture negative feelings towards local brands. This is a good sign for local brand owners, as it indicates that domestic consumers have favourable attitudes towards local brands. 
Despite having an insignificant direct effect on consumers' attitudes towards local brands, the inferior image of locally made products has a significant indirect effect on local brand identity misclassification. This means that the unfavourable image of local electronic products plays a large role in domestic consumers' attitudes through its effect on their misclassification of local brand identities. This finding, therefore, should encourage local brand owners to reduce confusion and improve domestic consumer attitudes.

In contrast to Hypothesis 4, the final hypothesis is strongly supported by our data. The findings suggest that, when consumers misclassify local brand identity, they tend to show a negative attitude towards local brands. This means that, when consumers wrongly classify reputable local brands as foreign ones, they still have an inferior image of (and thus negative attitude towards) local brands. When they are unable to recognise local brands due to their imitated identities and view that good brands come from other countries, they will perceive local brands negatively. This supports the argument of Zhou et al., 2010; Balabanis and Diamantopoulos, 2011; Magnusson et al., 2011 that, regardless of accuracy, misperceived brand origin still has a strong impact on consumers' attitudes towards brands.

\section{Implications}

From a theoretical viewpoint, this study contributes to the ongoing debate on the antecedents and consequences of brand origin misclassification. First, the findings of the study extend our understanding that a strong halo effect from countries with favourable images will generate confusion among the domestic consumers, who will perceive local brands as coming from countries with more favourable images. It also induces a negative attitude towards local brands, as the consumers believe favourable brands only come from countries with a strong positive halo effect. Second, this study finds that, because locally made products are unfavourably perceived, there is a greater tendency for local consumers to misclassify local brands as foreign ones. Nevertheless, this inferior image does not generate a negative attitude towards local brands. Consumers still have good perceptions of local brands; they just do not have sufficient knowledge of local brands. This study confirms that, when consumers in a developing country misperceive local brands as foreign ones (from more developed countries), this perception will greatly affect their attitudes towards the brands.

This study finds that Indonesian consumers may exhibit similar behaviour towards brands from industrialised Asian countries. These findings should be considered by local brand managers. First, the results indicate that the halo effect of brands from these industrialised countries generates confusion among Indonesian consumers. This indicates that local brands in developing countries can have images that are favourable or even as good as those of foreign competitors. Second, the inferior image of locally made electronic products drives consumers confusion. This suggests that local brand owners should focus on improving product innovativeness, quality, design, technology, performance, and value rather than adopting foreign-sounding brand names and thereby creating confusion among consumers. Third, the study found that, although consumers have an inferior image of locally made products, they do not necessarily have a negative attitude towards local brands. Rather, they simply do not know that reputable local brands are available. There is a strong need to clearly reveal the true origin of local brands. All of these strategies may enhance domestic consumers' perceptions of and attitudes towards local products and brands. This finding can support the Indonesian government's "buy local" product campaigns. Foreign brand owners, especially from the 
three countries studied, may cultivate favourable perceptions of their countries and brands. Nevertheless, they must be aware that, when Indonesian consumers become more knowledgeable about local brands due to local brand owners' revealing of their origins, Indonesian consumers' attitude towards local brands may improve. If this happens, foreign brand owners may face tougher competition in the Indonesian market and be required to develop and rely on new strategies to compete with local brands.

\section{Conclusion}

In recent years, brand origin misclassification has attracted increased attention among researchers. However, an interesting research gap exists regarding the role of the halo effect of foreign brands and the inferior image of local products toward brand identity misclassification. To fill this gap, the current study examined the effect of the halo effect of brands from Japan, South Korea, and China and the inferior image of locally made electronic products on brand identity misclassification and consumer attitudes towards local brands in Indonesia. Overall, this study finds that Indonesian consumers tend to misclassify favourable and strong local brands, this is energised by the strength of halo effect of brands from those favourable countries. The misperception is greatly strengthened by consumers' inferior image of domestically made products.

\section{Limitations and future research direction}

This study has a number of limitations. It only investigated local consumer behaviour within the context of one product category; as such, we recommend that future studies explore a wider range of product categories in order to provide a richer understanding of consumers' attitudes towards local brands in different product categories (such as fashion and food products), which may be immune to the halo effect of foreign brands. Additionally, the cross-sectional approach of this study limits its ability to develop stronger conclusions about linkages. This study only obtained data from young consumers; future studies should compare the behaviour of a wide range of consumer segments with different demographic backgrounds. Last but not least, this study investigated consumers' attitudes towards local brands rather than the actual brands they purchase or use. Taking this into account may provide a more comprehensive explanation of consumer behaviour in developing countries.

\section{Acknowledgements}

The authors have been fortunate, as a number of people helped for this publication. The authors have been assisted by colleagues, who participated in data collection and provided useful ideas and views, especially Professor Augusty T. Ferdinand from the University of Diponegoro, Central Java-Indonesia. Also, the authors thank to all students who participated in the study.

\section{References}

Balabanis, G., and Diamantopoulos. A. (2011). "Gains and Losses from the Misperception of Brand Origin: The Role of Brand Strength and Country-of-Origin Image". Journal of International Marketing Vol. 19, No. 2, pp: 95-116.

Barbu, C. M. (2011). "The Meanings of "Made in Romania" among the Romanian Consumers". Theoretical and Applied Economics Vol. XVIII, No. 7, pp:31-42. 
Bhardwaj, V., A. Kumar, and Kim. Y.-K. (2010). "Brand Analyses of U.S. Global and Local Brands in India: The Case of Levi's". Journal of Global Marketing Vol 23, pp: 8094.

Bloemer, J. E., Brijs, K. and. Kasper, H. (2009). "The CoO-ELM model: A theoretical framework for the cognitive processes underlying country of origin-effects". European Journal of Marketing Vol 43, No. 1/2, pp:62-89.

Borah, A., and Tellis, G. J. (2016). Halo (Spillover) Effects in Social Media: Do Product Recalls of One Brand Hurt or Help Rival Brands? Journal of Marketing Research, Vol. LIII (April), pp:143-160.

Bruwer, J., C. Buller, Saliba, A. J. and Li. E. (2014)."Country-of-origin (COO) brand loyalty and related consumer behaviour in the Japanese wine market". International Journal of Wine Business Research Vol. 26, No. 2, pp: 97-119

Chang, C. (2008). "The Effectiveness of Using global look in an Asian Market". Jounal of advertising research June, pp:199 - 214.

Chu, P.-Y., Chang, C.-C. Chen, C.-Y.and Wang. T.-Y. (2010). "Countering negative countryof-origin effects The role of evaluation mode". European Journal of Marketing Vol. 44, No. 7/8, pp:1055-1076.

Diamantopoulos, A., Schlegelmilch, B. B. and Palihawadana. D. (2009)." Country of Origin: A construct past its sell by date?" American Marketing Association winter, pp: 318 $-327$.

Fornell, C., \& Larcker, D. F. (1981). "Evaluating structural equation models with unobservable variables and measurement error", Journal of Marketing Research, Vol. 18, No. 1, pp: 39-50.

Ghodeswar, B. M. (2008). "Building brand identity in competitive markets: a conceptual model", Journal of Product \& Brand Management, Vol. 17, No. 1, pp:4-12

Han, C.M. (2016)."Global identity strategy and its efficacy for Asian brands: Is Toyota global or Japanese to consumers? Asia Pacific Journal of Marketing and Logistics, Vol. 28, No. 5, pp:862-877, https://doi.org/10.1108/APJML-11-2015-0173

Hair, J.F., Black, W.C, Babin, B.J., Anderson, R.E., and Tatham, R.L. (2010). "Multivariate Data Analysis". Pearson Education International. New Jersey.

Iversen, N. M., and Hem. L. E. (2011). "Reciprocal transfer effects for brand extensions of global or local origin: evidence from Norway". International Marketing Review Vol. 28, No. 4, pp:365-411

Koubaa. Y., (2008). "Country of origin, brand image perception, and brand structure, Asia Pacific Journal of Marketing and Logsitics, Vol. 20 No. 2, pp: 139-155.

Lee, R., Lockshin, L. and Greenacre. L. (2016). "A Memory-Theory Perspective of CountryImage Formation". Journal of International Marketing Vol. 24, No. 2 pp:62-79.

Magnusson, P., Westjohn, S. A. and Zdravkovic. S. (2011). "What? I thought Samsung was Japanese": accurate or not, perceived country of origin matters". International Marketing Review, Vol.28 No. 5, pp:454-472.

Mandler.T., Won, S. and Kiom, K. (2017). "Consumers' cognitive and affective responses to brand origin misclassifications: Does confidence in brand origin identification matter?" Journal of Business Research, Vol. 80, pp: 197-209.

Oh, M.-Y., and Ramaprasad, J. (2003). "Halo effect: Conceptual definition and empirical exploration with regard to South Korean subsidiaries of US and Japanese multinational corporations". Journal of Communication Management Vol.7, No. 4, pp:317-330 
Özsomer, A. (2012)."The Interplay Between Global and Local Brands: A Closer Look at Perceived Brand Globalness and Local Iconness". Journal of International Marketing Vol. 20 No. 2, pp:72 - 95.

Pham, H. C., and Richards. B. (2015). "The western brands in the minds of Vietnamese consumers". Journal of Consumer Marketing Vol. 32 No.5:http://dx.doi.org/10.1108/JCM-09-2014-1159

Panda, R., and Kapoor, D. (2016), "Managing loyalty through brand image, judgment and feelings for leveraging power brands", Management \& Marketing Challenges for the Knowledge Society, Vol. 11, No. 4, pp. 624-637, DOI: 10.15.15/mmcks-20160020.

Sääksjärvi, M., and Samiee. S. (2011)."Relationships among Brand Identity, Brand Image and Brand Preference: Differences between Cyber and Extension Retail Brands over Time". Journal of Interactive Marketing Vol. 25, pp:169-177.

Spence, M., and Essoussi. L. H. (2010). "SME brand building and management: an exploratory study". European Journal of Marketing Vol. 44, No. 7/8, pp:1037-1054

Srivastava, R. K. (2011). "Understanding brand identity confusion". Marketing Intelligence \& Planning Vol. 29, No. 4, pp:340-352.

Sulhaini, Rusdan, Dayani, R., Sulaimiah and Ismiwati, B. (2019)."Local brand origin knowledge of young consumers in a developing country", Int. J. Applied Management Science, Vol. 11, No. 1, pp: 72-90.

Sulhaini. (2016). "Home country image and ethnocentrism among young consumers in a developing country". Journal for Global Business Advancement Vol. 9, No. 2, pp:195 $-211$.

Sulhaini, and Mulyono. L. E. H. (2015). "The Effect of Ethnocentrism and Image of Asian Industrialised Countries on Perceived Relative Qualit"y. International research Journal of Business Studies Vol. 7, No. 3, pp:165- 177.

Sullhaini, and Sagir.J. (2015). "Identifying Interesting Themes Regarding Country of Origin Effect: A Preliminary Study". Proceeding of the 12th UBAYA International Annual Symposiun on Management Makassar - Indonesia, pp:892 - 906.

Vance, L., Raciti, M. M. and Lawley, M. (2016). "Beyond brand exposure: measuring the sponsorship halo effect". Measuring Business Excellence Vol. 20, No.3, pp:1-14.

Zhou, L., Yang, Z. and Hui, M. K. (2010). "Non-local or local brands? A multi-level investigation into confidence in brand origin identification and its strategic implications". Journal of the Academy Marketing. Science. Vol. 38, pp:202-218.

Zhuang, G., Wang, X., Zhou, L. and Zhou. N. (2008). "Asymmetric effects of brand origin confusion Evidence from the emerging market of China. International Marketing Review Vol. 25, No. 4. pp:441-457

\section{Appendix Measurement results}

Brand halo effect strength (Japan); $\lambda: 0.60$ - 0.85 Cronbach's $\alpha: 0.786$ CR: 0.80 AVE:0.50 Brand halo effect strength (S. Kor); $\lambda: 0.60-0.82$ Cronbach's $\alpha: 0.855$ CR: 0.85 AVE: 0.53

Brand halo effect strength (China); $\lambda: 0.68-0.85$ Cronbach's $\alpha: 0.872$ CR: 0.87 AVE: 0.56

All brands from this country are of high value

All brands from this country have remarkable performance

All brands from this country are of high quality

All brands from this country are great*

All brands from this country are symbol of advance technology

Inferior image of local products $\lambda: \quad 0.54-0.85$ Cronbach's $\alpha: 0.874$ CR: 0.88 AVE: 0.51 
Unattractive design*

Non-innovative products*

Lack of model variety

Technology backward

Lack of operating performance

Bad overall quality

Lack of durability

Not Prestige*

Lack of value for money*

In attractive price

Lack of product serviceability

Local brand identity misclassification $\lambda: 0.59-0.85$ Cronbach's $\alpha: 0.838$ CR: 0.84 AVE: 0.57

Brand knowledge (list of ten local brand)

All modern look brands must come from abroad*

All brands with positive reputation must come from abroad

All brands with foreign names show their origin from abroad

All prestigious brands must come from abroad*

All brands with glamour appearance must come from abroad

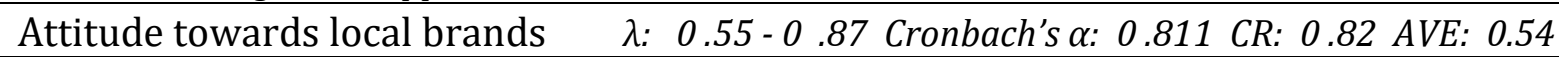

\section{Liking}

Preference

Chose

Next purchase

${ }^{*}$ Deleted items 